\title{
DEVELOPMENT OF NATIONAL EMISSION FACTORS FOR SOLID WASTE DISPOSAL ON LAND GREENHOUSE GAS SOURCE CATEGORY OF THE NATIONAL INVENTORY IN THE REPUBLIC OF MOLDOVA
}

\author{
Tatiana Țugui ${ }^{\mathrm{a} *}$, Gheorghe Duca ${ }^{\mathrm{b}}$, Marius Țăranuc \\ ${ }^{a}$ State University of Moldova, 60 Mateevici Str, Chisinau, Republic of Moldova \\ ${ }^{b}$ Academy of Sciences of Moldova, 1 Stefan cel Mare Bd. Chisinau, Republic of Moldova \\ ${ }^{c}$ Climate Change Office, Ministry of Ecology and Natural Resources, 9 Cosmonautilor Str. MD 2005 Chisinau, Republic of Moldova \\ *E-mail: tugui@mediu.moldova.md, tel.37322 204527
}

\begin{abstract}
The paper summarizes the research results on development national emissions factor for the Greenhouse Gas Inventory (GHGI) Source Category "6A Solid Waste Disposal on Land". The obtained results offer the opportunity to improve the Intergovernmental Panel for Climate Change (IPCC) methodologies and Emission Factors for assessing the GHG emissions originated from waste sector. The article contains relevant information on composition of landfill gases at managed and unmanaged solid waste disposal sites, as well as the municipal solid waste composition results, investigated during one year in the Republic of Moldova: from autumn, 2004 to summer, 2005.
\end{abstract}

Keywords: solid waste disposal, greenhouse gas, methane emissions, landfill gas measurements.

\section{Introduction}

Urbanization and economic development have increased waste generation in whole world. In the $21^{\text {st }}$ century, the treatment of waste has become a serious environmental concern and waste management continues to be an important environmental challenge. Waste management and climate change are closely related. For instance, solid waste disposal sites are one of the largest sources of greenhouse gas (GHG) - methane emissions. The methodology used to estimate emissions from waste activities requires country-specific knowledge on waste generation, composition and management practice. In this context the main objective for this study has been to compile results of the municipal solid waste composition, as well as landfills gas (LFG) measurements on managed and unmanaged landfills in the Republic of Moldova. These studies were carried out during one year, monthly for landfill gas measurements and seasonally for waste composition analyses.

\section{Results and Discussions}

The obtained results from field studies indicated that solid waste composition slightly varied seasonally and is indicated in the table 1 .

Table 1: Seasonable waste composition results in the Republic of Moldova, 2004-2005

\begin{tabular}{|c|c|c|c|c|c|c|c|c|c|c|c|c|}
\hline \multirow{3}{*}{ 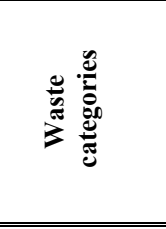 } & \multicolumn{3}{|c|}{ Autumn 2004} & \multicolumn{3}{|c|}{ Winter 2005} & \multicolumn{3}{|c|}{ Spring 2005} & \multicolumn{3}{|c|}{ Summer 2005} \\
\hline & $\begin{array}{l}\bar{x} \\
8\end{array}$ & $\begin{array}{l}\bar{x} \\
a\end{array}$ & 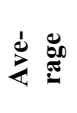 & ¿̇ & $\underset{\stackrel{\infty}{\sim}}{\square}$ & 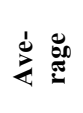 & $\begin{array}{l}\Xi \\
\dot{\sim}\end{array}$ & $\underset{i}{\stackrel{0}{n}}$ & 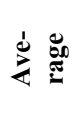 & $\begin{array}{l}\bar{\nabla} \\
\dot{2}\end{array}$ & $\frac{B}{8}$ & $\sum_{4}^{d}$ \\
\hline & $\%$ & $\%$ & $\%$ & $\%$ & $\%$ & $\%$ & $\%$ & $\%$ & $\%$ & $\%$ & $\%$ & $\%$ \\
\hline Paper & 5.7 & 4.5 & 5.1 & 8.7 & 8.3 & 8.5 & 9.5 & 6.6 & 8.0 & 5.3 & 7.3 & 6.3 \\
\hline Glass & 5.2 & 2.9 & 4.1 & 6.2 & 11 & 8.6 & 7.6 & 7.7 & 7.7 & 8.4 & 7.6 & 8.0 \\
\hline Plastic & 10.8 & 8.6 & 9.7 & 11.5 & 15.4 & 13.4 & 13.4 & 10.5 & 12.0 & 11.1 & 16.2 & 13.7 \\
\hline Metals & 3.9 & 2.2 & 3.1 & 4.0 & 3.7 & 3.9 & 2.7 & 5.4 & 4.0 & 5.0 & 6.2 & 5.6 \\
\hline Food remains & 63.1 & 66.5 & 64.8 & 48.1 & 53.2 & 50.7 & 53.5 & 56.6 & 55.1 & 54.8 & 51.6 & 53.2 \\
\hline Garden waste & 1.4 & 3.7 & 2.5 & 1.0 & 0.8 & 0.9 & 1.2 & 0.9 & 1.0 & 3.7 & 1.0 & 2.4 \\
\hline Textile & 4.3 & 5.5 & 4.9 & 12.2 & 3.5 & 7.8 & 4.5 & 2.5 & 3.5 & 2.6 & 3.1 & 2.8 \\
\hline Wood & 1.8 & 1.6 & 1.7 & 1.3 & 1.4 & 1.4 & 0.6 & 2.4 & 1.5 & 2.1 & 2.6 & 2.3 \\
\hline Construction & 2.2 & 3.6 & 2.9 & 6.4 & 1.6 & 4.0 & 6.5 & 6.3 & 6.4 & 5.5 & 3.3 & 4.4 \\
\hline Leather & 1.6 & 0.9 & 1.2 & 0.6 & 1.1 & 0.8 & 0.4 & 1.1 & 0.8 & 1.5 & 1.1 & 1.3 \\
\hline
\end{tabular}

It should be mention that we consider householders generate the composition of waste, which is disposed at landfill and not that. MSW are collected in the open containers and scavengers recover usually recyclable fractions. This fact led to reduction of paper fraction in the MSW, but does not affect fraction of plastic packaging, which counted about $13 \%$ by weighing and even more times by volume. The food wastes represent almost $50 \%$ of the waste stream.

Data on municipal solid waste composition is used for the estimation of national value for DOC, which represents the value of 0.146. The same value of 0.146 can be obtained if the Extended Buswell Equation is used as well (Table 3).

First measurements of biogas composition have been undertaken at Straseni landfill weekly during one month. As no fluctuation of biogas components was observed, it was decided to monitories emissions monthly. Researches and 
LFG measuring on this landfill have revealed that the depth of a landfill and the thickness of the waste layer are very important for the formation of LFG. It was demonstrated that a landfill with the thickness of waste layer around 5-8 $\mathrm{m}$ generate a low concentration (around 20 per cent) of $\mathrm{CH}_{4}$ (Figure 1).

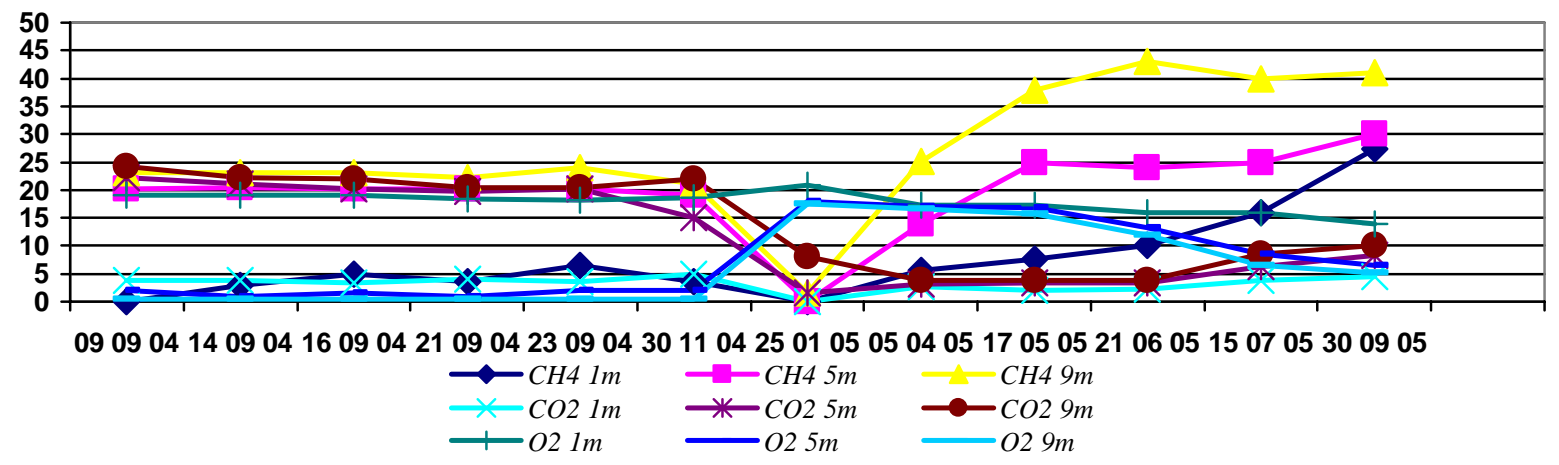

Figure 1: Dynamics of biogas measurement at Straseni landfill

In order to verify the results of chromatography analysis, using measuring devices «GASOTEST» TU 4215001-17763771-95 performed an additional measurement of CO2 and $\mathrm{O} 2$ concentrations. The graphic below illustrated the results of both analyses (Figure 2).

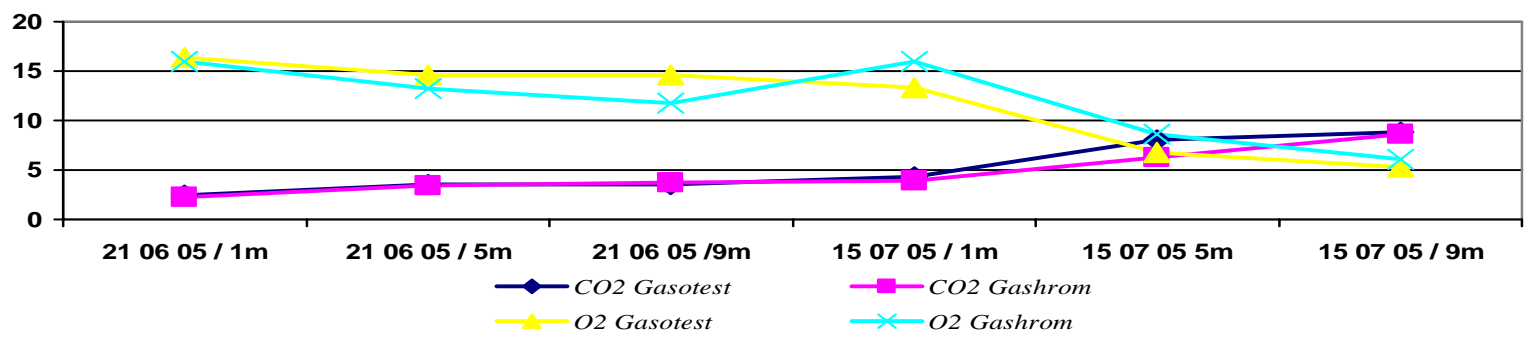

Figure 2: Comparison between express analysis and chromatograph of $\mathrm{O}_{2}$ and $\mathrm{CO}_{2}$ emissions at Străşeni landfill

During the research period at Balti landfill the $\mathrm{CH}_{4}$ emissions are constantly produced, their concentration had fluctuated between $45-80 \%$, depending by the level of taking measurements. For a deeper level like 5-9 $\mathrm{m}$, the $\mathrm{CH}_{4}$ concentration practically is not influenced by seasonal temperature fluctuation, but at the level of $1 \mathrm{~m}$ it was observed a reduction of $\mathrm{CH}_{4}$ in the cold period of year (Figure 3).

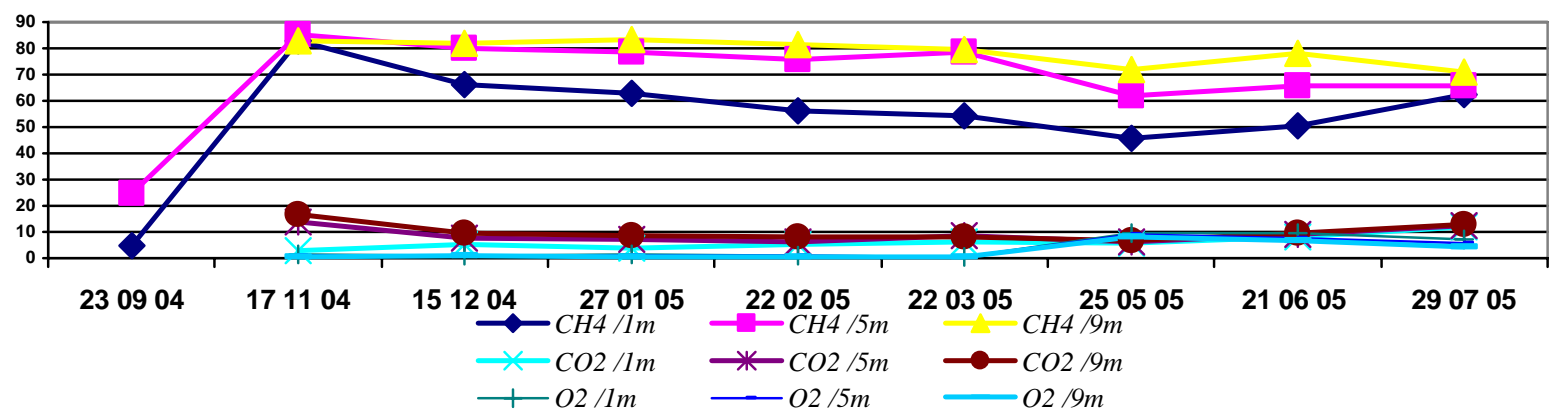

Figure 3: Dynamics of biogas measurement at Bălți landfill

In addition, the $\mathrm{CO}_{2}$ emissions have been measured by using the device „GAZOTEST” TU 4215-00117763771-95. For the first measurement, the biogas concentration (it was collected on 22.03.2005) was analyzed in laboratory conditions. The obtained results revealed the following: the concentration of $\mathrm{O}_{2}$ is $0.5-0.4 \%$, while the $\mathrm{CO}_{2}$ concentration remained constant (11.6\%) for all the taken samples: from 1, 5 and 9 meter levels (Figure 4). 


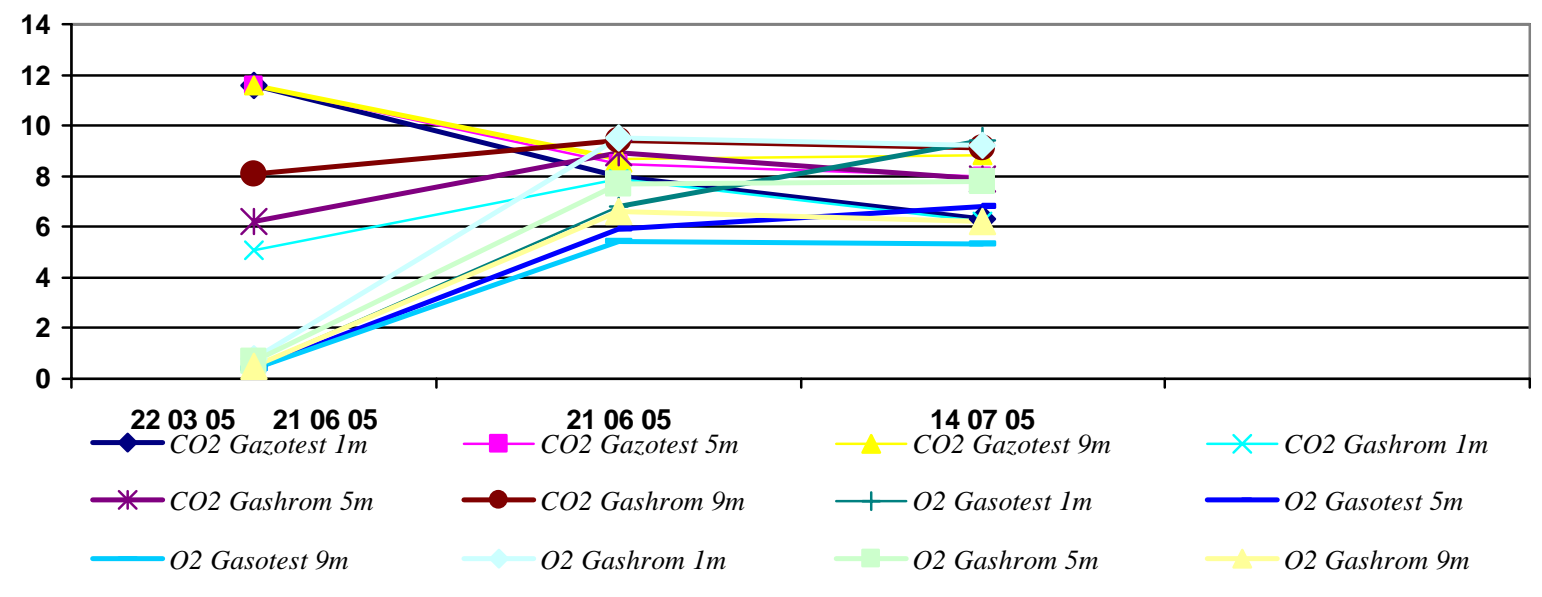

Figure 4: Comparison between express analysis and chromatograph of $\mathrm{O}_{2}$ and $\mathrm{CO}_{2}$ emissions at Bălți landfill

Samples collected on 21.06.05 and 14.07.05 have been analyzed directly at well, at the landfill. The obtained results defer from the previous one. First of all, the $\mathrm{O}_{2}$ concentration has changed in dependence of the level, from $1 \mathrm{~m}$ to $9 \mathrm{~m}\left(6.8 \%\right.$ and $5.4 \%$, respectively), also the $\mathrm{CO}_{2}$ concentration has increased from $8.0 \%$ to $8.7 \%$ for the 9 -meter level. At the same time, the obtained results are comparable with the results of the chromatography analyzes of the biogas (Figure 5).

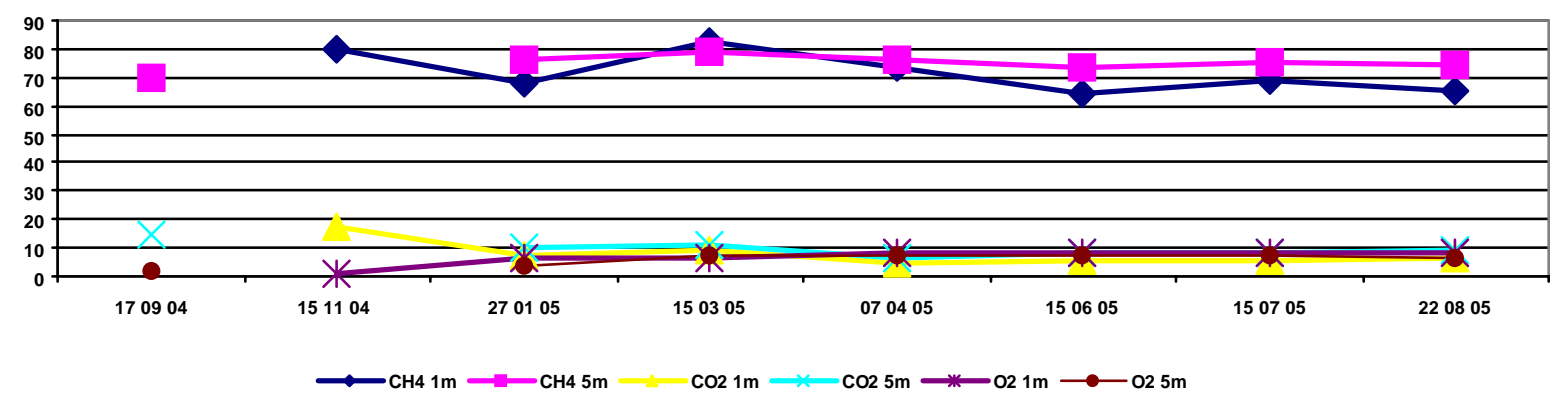

Figure 5: Dynamics of biogas measurement at Chisinau landfill

Nevertheless the concentration of $\mathrm{CH}_{4}$ at Chisinau landfill is lower than at Balti landfill, this fact might be explained by the using of the technique of landfilling with separate waste layers at the first one. Generally it is expected that the production of LFG on landfills with separate waste layers is less than on landfills with one waste layer, because layers of covering materials has significant impact on the forming of LFG [1]. This assumption was confirmed by our results what is indicated in the Table 2.

In addition to the chromatograph analysis, other measuring device (GAZOTEST TU 4215-001-17763771-95) has been used on 15.07.2005 with the scope of detecting the presence of $\mathrm{CO}_{2}$ and $\mathrm{O}_{2}$ at Chisinau landfill. The obtained results are presented below (Figure 6).

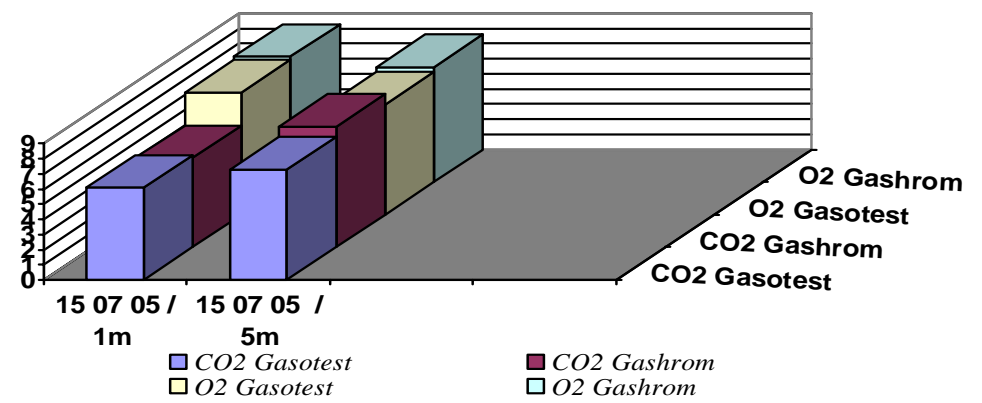

Figure 6: Comparison between express and chromatograph analysis of $\mathrm{O}_{2}$ and $\mathrm{CO}_{2}$ at $\mathrm{Chisinau}$ landfill

The results of measurements at three landfills from the republic of Moldova revealed the variability of landfill gas composition from one site to another. This fact might be explained, first of all, by landfill characteristics: in the case of Balti and Chilinau, they are managed landfill while the last one, from Straseni town, it is unmanaged. The table below contains the usual biogas composition and the obtained results characteristic for the Republic of Moldova [2]. 
Table 2: Obtained results on composition of gases at three landfills in the Republic of Moldova (h=5-9 meters)

\begin{tabular}{|c|c|c|c|c|c||}
\hline Gases & $\begin{array}{c}\text { Usual LFG } \\
\text { composition, \% }\end{array}$ & $\begin{array}{c}\text { LFG } \\
\text { composition } \\
\text { Chisinau landfill *, } \\
\%\end{array}$ & $\begin{array}{c}\text { LFG composition } \\
\text { Balti landfill, \% }\end{array}$ & $\begin{array}{c}\text { LFG } \\
\text { composition } \\
\text { Straseni } \\
\text { landfill, } \\
\%\end{array}$ & $\begin{array}{c}\text { Average LFG } \\
\text { composition, in RM, \% }\end{array}$ \\
\hline \hline $\mathrm{CH}_{4}$ & $50-60$ & $71-75 / 63-65$ & $74-79$ & $23-45$ & $56-66$ \\
\hline $\mathrm{CO}_{2}$ & $30-40$ & $8-10 / 32-34$ & $9-10$ & $12-14$ & $10-12$ \\
\hline $\mathrm{N}_{2}$ & $5-32$ & $10-16$ & $10-16$ & $50-60$ & $15-30$ \\
\hline $\mathrm{O}_{2}$ & $0-2$ & $5-6 / 0.5-1$ & $3-5$ & $7-8$ & $5-7$ \\
\hline
\end{tabular}

* Alternative results have obtained from CDM Projects "Landfill gas utilization at Chisinau landfill" (donor: DEPA, Denmark Kingdom, beneficiary: Mayoralty of Chisinau).

It should be mentioned, that $\mathrm{CH}_{4}$ generation depends also on the quantities of MSW disposed at landfill, in the case of Straseni landfill the MSW it is many times less then at the landfills from Balti and Chisinau. The Extended Buswell Equation was used for the estimation of methane fraction in landfill gas (the obtained results are presented in Table 3).

Table 3: Fraction of methane in landfill gas $(F)$

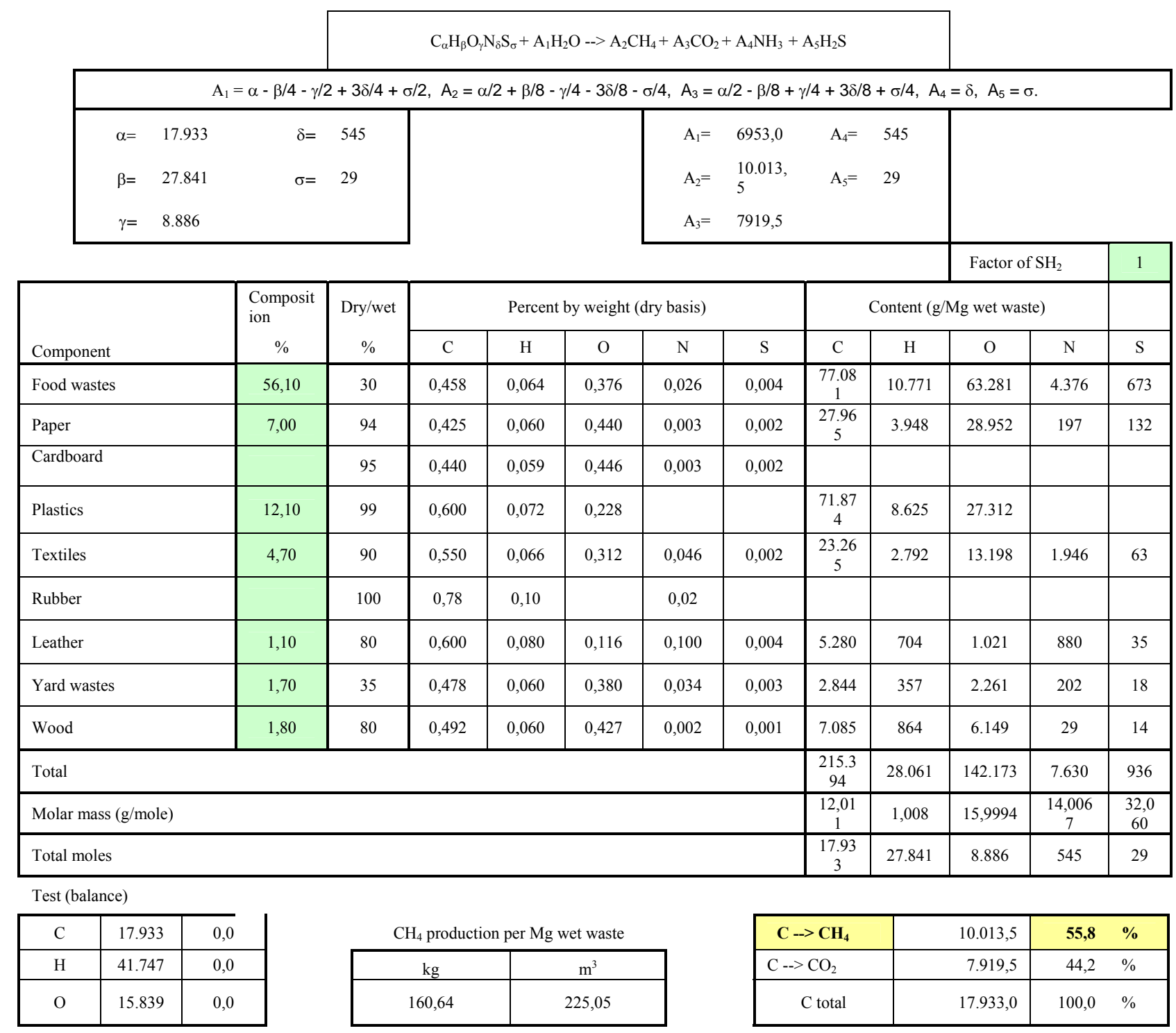

\section{Conclusions}

The main conclusion and findings related to the consolidating data from landfill gas measurements and solid waste composition at national level are presented below: 
1. Data on composition of municipal solid waste have been used for the estimation of national parameter of $\mathrm{DOC}=0.146$ and $\mathrm{DOC}_{\mathrm{f}}=0.585$, based on IPCC methodology and the Extended Buswell Equation.

2. Based on the comparison between express and chromatography analyses it could be concluded what the chromatography analyses might be accepted for using, as the differences between the two methods is around $\pm 10 \%$, which is in frame of limited errors for measurement devices.

3. The obtained results for the LFG measurements during a year, offer the opportunity to update the IPCC EFs for $\mathrm{CH}_{4}$ emissions from landfills for the Republic of Moldova, by using the 0.6 instead of 0.5 value, which was used before in the First National Communication to the UNFCCC [3].

4. The decision on using the value of 0.6 as EFs for $\mathrm{CH}_{4}$ is confirmed also by the results presented into the Table 3 (the fraction of $\mathrm{CH}_{4}$ in biogas is $55.8 \%$, which is close to the average value of the LFG composition presented in Table 2).

\section{Experimental}

Municipal solid waste (MSW) composition surveys were performed at transfer station in Chisinau municipality and humidity analyzes at Central Ecological Laboratory of the State Ecological Inspectorate of the Republic of Moldova. Waste characterization surveys provide the percentage by weight of each major category of waste in the overall waste stream. Relevant details on the used methodology can be found in the article [4]. The obtained results are summarized as well in the table 1 above. Based on the Revised 1996 IPCC methodology and by using the data obtained, the national value for DOC (degradable organic carbon) was estimated.

Under UNDP/GEF Regional Project "Capacity Building for Improving the Quality of Greenhouse Gas Inventories (Europe and CIS region)", Georgia prepared and proposed the new methodology (approach) to estimate degradable organic carbon (DOC) and fraction of degradable organic carbon dissimilated $\left(\mathrm{DOC}_{\mathrm{F}}\right.$ ) for waste components and for total waste taking into account lignin content in waste (for both cases including and excluding lignin). The Approach (Methodology) is based on results of the laboratory experiments conducted by Dr. Morton Barlaz [5-7] and on investigations of I.Chandler et al. [8] and Van Soest [9]. "MSW Learning Tool" of the University of Central Florida [10] also was used. In the methodology also is presented the method (based on the Extended Buswell Equation) for estimating fraction of $\mathrm{CH}_{4}$ in landfill gas $(\mathrm{F})$.

Follow this model and using national data on solid waste composition, there were estimated the DOC, DOCf values and biogas composition at managed and unmanaged landfills from the Republic of Moldova. Table 4 reveals the obtained results [11].

Table 4: Degradable Organic Carbon and Fraction of Degradable Organic Carbon Dissimilated (DOC and $\mathrm{DOC}_{\mathrm{F}}$ )

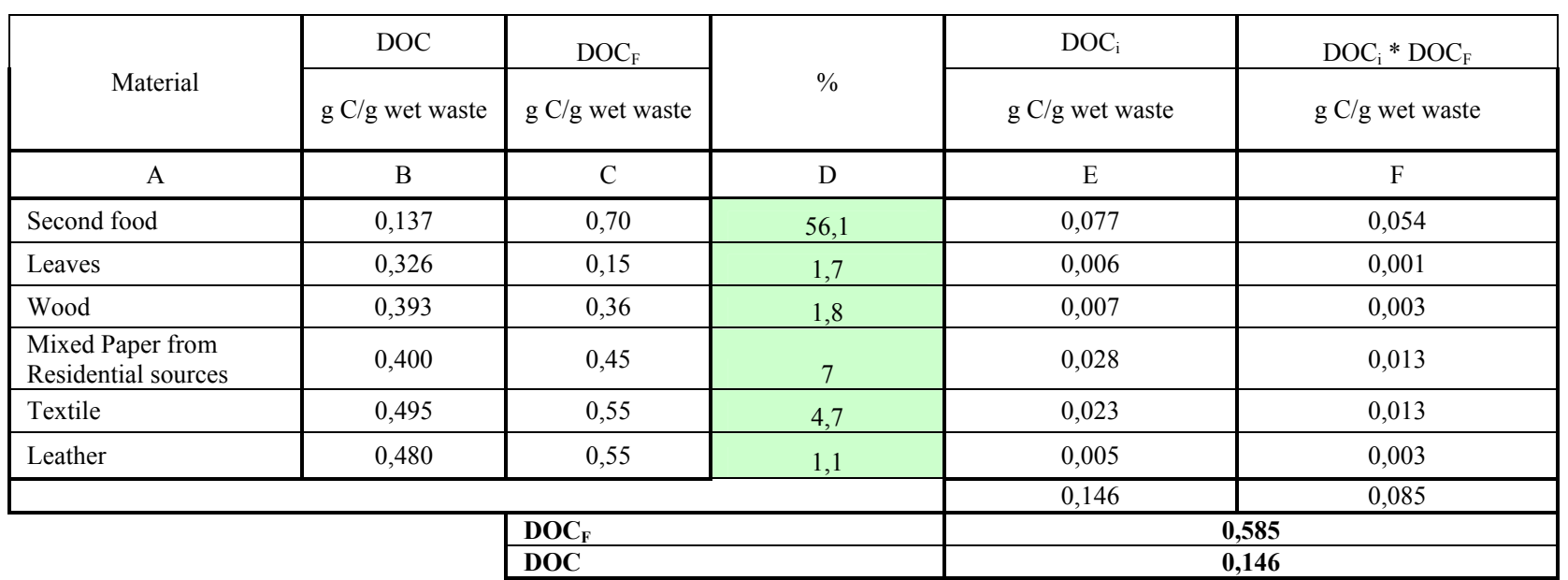

Landfill gas measurements were performed at three landfills from Straseni and Balti towns and Chisinau Municipality (the landfill is located near the Cretoaiea village). Landfill biogas was collected from special wells installed in 2004 and investigated chromatographically at the Central Ecological Laboratory of the State Ecological Inspectorate, which has a respective accreditation [12, 13]. Also, express analysis for $\mathrm{CO}_{2}$ and $\mathrm{CH}_{4}$ were conducted directly at landfills. The following equipments were used during measurements: aspirator "AM-5", "GIAM-305" portable gas analyzer, chromatograph “GAZHROM-3101” and „GAZOTEST” TU 4215-001-17763771-95.

\section{References}

[1] Bingemer, H.G., Crutzen, P.J. The production of methane from solid waste, Journal of Goephysical Research, 92(D2):1987, pp.2181-2187.

[2] Ham, R.K., Barlaz M.A. Measurement and Prediction of Landfill Gas Quality and Quantity, ISWA Symposium on Process, Technology and Environmental Impact of Sanitary Landfills: Sardinia, 1987, p.VIII, pp 1-24. 
[3] Ministry of Ecology and Territorial Development/UNDP Moldova, First National Communication of the Republic of Moldova, Submission to the UNFCCC at COP-6: Chisinau, 2000. 74 pages.

[4] Țugui, T.; Duca, Gh.; Țăranu, M.; Mîrza, V.; Drăguțan, I. Municipal solid waste composition study; The Bulletin of the Academy of Sciences of Moldova, Series "Biological, Chemical and Agricultural Sciences". N.4, Chişinău, 2004; pp. 114-119.

[5] Barlaz, M. A. Biodegradative Analysis of Municipal Solid Waste in Laboratory-Scale Landfills, EPA 600/R-97071.

[6] Solid Waste Management and Greenhouse Gases. A Life-Cycle Assessment of Emissions and Sinks. $2^{\text {nd }}$ EDITION. EPA 530-R-02-006).01, 1997.

[7] Barlaz M. A., Eleazer W. E., Odle W. S., Qian III. X., and Wang Y-S.. "Biodegradative Analysis of Municipal Solid Waste in Laboratory-Scale Landfills". Project summary. EPA 600/R-97-071

[8] Chandler, J.A., Jewell W.J., Gossett J.M., Van Soest P.J., and Robertson J.B... Predicting methane fermentation biodegradability. Biotechnology and Bioengineering Symposium No. 10, 1980, pp. 93-107.

[9] Richard T. The Effect of Lignin on Biodegradability. "Cornell Composting - Science \& Engineering".

[10] MSW Learning Tool. University of Central Florida.

[11] IPCC Revised 1996 IPCC Guidelines for National Greenhouse Gas Inventories Vol 1-3, Intergovernmental Panel on Climate Change, 1997.

[12] Tugui, T., Duca, Gh., Taranu, M., Copacinschi, Gh., Dragutan, I. Landfill gas emissions measurements in the Republic of Moldova. The 3rd International Conference "Ecological Chemistry":, Chisinau, 2005; pp. 365-366.

[13] Tugui, T., Duca, Gh., Taranu, M., Copacinschi, Gh., Dragutan, I. Assessment of Landfill Gas Generation. The International Conference "Hazards Mitigation": Chisinau, 2005; pp. 219-225. 